\title{
Critical Thinking on Technology Use: Higher Education Course Design to Promote Personal, Professional and Societal Change
}

\author{
Susan K. Walker, Rebecca Leaf Brown \\ Department of Family Social Science, University of Minnesota, St Paul, Minnesota
}

\begin{abstract}
Higher education is a venue for developing critical thinking skills, dispositions and actions (Davies, 2015). With the exponential growth of information and communications technologies (ICT) in the last thirty years, dynamic changes and societal impacts, and evolving research findings, intentional use for personal and professional well-being depends on emerging adults' critical thinking abilities. This paper describes the design of an undergraduate course and elements of critical thinking deployed through content, learning activities and assessments. Thematic analysis of student qualitative responses at the end of the course indicate specific areas of growth that represent gains in cognitive skills, dispositions and action orientations. These validate the selected methods of instruction and underscore the course design, content and pedagogical framework as applicable to a wide range of content areas and field domains in higher education.
\end{abstract}

Keywords: critical thinking; dispositions; technology use; preprofessional standards. 


\section{Introduction}

A hallmark value of higher education is the acquisition of critical thinking skills that transfer to learners' future personal and professional lives and apply to their roles as global citizens (Casigrahi, 2017; Niu, Behar-Horentstein, \& Garvan, 2013). Davies' (2015) model of critical thinking in higher education asserts that instructors and instructional designers integrate opportunities for critical thinking skills, expression of dispositions and determination of social action into the curriculum. Frameworks such as Bloom's taxonomy (1956) have long guided higher education instructional designers and educators on providing learning experiences that challenge existing cognitions and develop competencies for decision-making. Rather than teaching critical thinking as a separate skill or implying the acquisition of critical thinking, courses that infuse critical thinking within domain content are more successful in building these skills in meaningful and sustained ways (Abrami, et al, 2008). Critical thinking and action is goal directed (Ryan \& Deci, 2000). Students in higher education experience a range of motivations for their learning, from personal (e.g., better understanding of oneself and direction in life); to practical (e.g., completing a degree), professional (e.g., gaining necessary competencies for a vocation), to global and societal (e.g, identifying steps toward wider change).

The use and presence of technology in our 21st century society is an aspect demanding attention to critical thinking experiences in higher education. Technology takes many forms and meanings, but concretely this means information and communications technologies (ICT) which include personal computing, social media, access to the Internet and digital devices, and learning technologies deployed in higher education. The topic is relevant for critical thinking competency-foci in higher education given that it touches on personal, professional and societal motivations of learners. The use of ICT is ubiquitous in emerging adults' lives, in their relationships and family connectivity, across fields of practice, and impacts society (Bialek \& Fry, 2019). It is essential that higher education learners possess the skills to assess use and ramifications on their development and well-being. Yet the dynamic nature and relative recency of the phenomenon of ICT use and research on its effects bring particular importance for students' skills as critical thinkers. The advent of social media, 'smart' phones and homes, and cloud computing is within the lifetimes of most students in higher education (i.e., since 1990). The research on developmental impact is in early stages (e.g., yet the continual change in device and application availability challenge the interpretation and application of the results). Because of this, the technology consumer (in this case student in higher education poised to an adulthood of professional practice and family life) is often faced with competing information about the benefits or challenges to technology use; a situation that can leave the individual stymied in determining best practice for oneself and others. Critical thinking and action skills are required to make intentional decisions about the use of devices amidst a sea of incomplete 
and changing data, and contexts that are inconsistent in their technology practices and supports (author).

This paper describes the creation and implementation of an undergraduate course on technology use with an emphasis on building learner critical thinking skills, dispositions and social actions. Although the course is embedded within the curriculum of a field (family studies) and adheres to domain principles, ethics and competencies specific to that field (e.g., National Council on Family Relations, 2014) its design presents a conceptual framework for the delivery of critical thinking skill instruction and activities that is widely applicable in higher education disciplines.

\section{Course Design}

\subsection{Course description}

Family Social Science 3105 Families and Technology is a 3 credit undergraduate course delivered at a midwestern public institution in the United States. It was developed in 2017 as a required course in the major. The classroom course is offered fall and spring semesters (15 weeks each) and heavily integrates technology for communication, content, collaboration and assessment during and between classes. On average 45 students are enrolled, representing learners across all undergraduate years. The course is listed as a "Technology and Society" elective by the university so approximately one fourth of the students represent non-family majors.

\subsection{Course development}

Design principles adhered to technology enhanced learning (ISTE, 2019; Wang \& Hannifin, 2015). Content resulted from the designer's thorough review of the research and practice literature on implementation of technology by families and by family practitioners (e.g., parenting educators, marriage and family therapists, family financial planners, author, 2015). The course designer is an experienced family education scholar with more than 30 years of teaching and research in the area, and with specialized research on family and professional technology use since 2005 (author). The literature review identified topics that represent family structure and process interests (e.g., from couple formation and the use of dating apps, through parent-child relationships and family connectivity, work-family balance), and theoretical foundations framing the study of family and technology use and impacts. The second content dimension considered higher education's role in building preprofessional competencies and experiences. Field standards (e.g., American Association of Family and Consumer Sciences, 2013, American Association of Marriage and Family Therapists, 2015) indicate digital skills and practice ethics inclusive of technology. The final dimension framing content is the wider ecology that influences technology use. 
Systems theory is a central tenet of family studies (Olson, DeFrain \& Skogrand, 2014) with the shared perspective that individuals act on and are influenced by their proximal (e.g., family) and distal (e.g., community, society) relationships and networks. Therefore, an integrative view on technology use considered research on the individual, family and society, technology as a practice and content focus for professionals, the needs for professional preparation, and wider systems of influence (author).

\subsection{Opportunities for building critical thinking skills, dispositions and actions}

Davies' (2015) model of critical thinking in higher education incorporates cognitive skills and arguments as the traditional and central feature. Competencies represent Bloom's taxonomy (knowledge, comprehension, application, analysis, synthesis, evaluation) and those represented in problem-solving and decision making models (Halpern, 1998). Critical 'propensities' further represent the 'critical thinking movement:' affective, dispositions, emotions, attitudes and states of readiness. These relate to the self (e.g, tolerance of ambiguity, perseverance, desire to be well-informed) to others (e.g., respect for alternative viewpoints, understanding of individual differences) and in relation to the world (e.g., interest, inquisitiveness) (p. 58) Critical consideration of social conditions and actions represent what Davies' describes as the 'criticality' movement and the more familiar critical pedagogy movement. These activities focus the learners' interest in the inequalities and conditions affecting technology use and identification of action for social change and justice.

Weekly presentation of content in class and in reading, weekly short quizzes and in class discussion of topics promote comprehension, analysis, application of content. Objectve items on three exams test for comprehension, analysis and application. Open ended questions enable the demonstration of independent decision making, affective perspectives on technologies choices (e.g., recommendations for parent action given ambiguous conditions), and asserting actions for social change (e.g., recommendations for reducing digital divides experienced by global families).

Students prepare five blog posts (about 1 every 3 weeks) addressing critical thought prompts representing course content. The posts appear on the student's personal blog (made public or private depending on the students' preference). Each post is approximately 1000 words and includes 2 artifacts from the course (e.g., readings, video). A sample prompt: "Listen to the podcast on the social media scandal at Harvard. What is your reaction to the ultimate decision related to a student's admission decision? Was it fair, given our current social media climate? Consider our class discussion about our individual use of technology and its additional impacts on others, and how our use is heavily influenced by others' expectations of us." Prompts encourage students to write from multiple perspectives on an issue, apply content, identify wider influences on technology use and encourage avenues 
for social change. A grading rubric assesses the quality of the post for clarity and incorporation of reliable sources, thus promoting student's digital literacy skills. It also assesses students' ability to critically apply, analyze or debate an alternative perspective.

Through an analysis project, students log their personal technology use for a 12 hour period and summarize quantitative. Then in a written paper, students analyze use relative to their personal well-being, and relationships (intimate, family, professional) and how the analysis informs their future work as family professionals. This critical thinking project enables a closer examination of behavior that has become familiar, unseen and unfelt to them as a generation who grew up with ICT (Bialek \& Fry, 2019) to weigh its value to their health, learning, social experiences and intimate and family relationships. They reflect on the myriad influences on their technology choices and behaviors and identify actions past, present or future to assert balance (e.g., addressing distractions, reducing time on social media as mental health intervention). A grading rubric indicates the quality of the product and ability to applying critical thinking elements to their use.

All class/small group activities in each module emphasize movement beyond critical thinking cognitions to dispositions and actions. These include debates that argue two or more sides, discussion of different viewpoints, factors that influence behavior and actions that represent change. For example, early in the course students debate whether laptops should be prohibited in the classroom (following calls by some in the academic community and learning research). The activity identifies personal motivations for use (or non-use), social impacts (e.g., distractions to others, ability to collaborate), and wider institutional factors that encourage use (or that represent challenges). Following the debate, the class deliberates on preferred community actions to ensure inclusion and group satisfaction. The activity moves students from a place of individual preference to the wider social context of the classroom and institutional policies that affect choice. Other debates include appropriate ages for childrens' smartphone possession, responsibility for consequences of cyberbullying, and privacy concerns when sharing personal information online. Comparative activities include differences in technology preferences, comfort, skill and access that encourage dispositions of tolerance and resource identification. Each activity is selected to build on content awareness and application to more dispositional and action elements of critical thinking.

\section{Course impacts and future perpsectives}

Assessing student competencies on exams and quizzes, and project and blog grading indicates student achievement on par with other content courses in the major. The majority of students scoring $80 \%$ and above. More revealing of the critical thinking acheivement of the course are in student comments. During the initial (2017) and recent (2019) semesters, 
students were asked to anonymously complete an open-ended question about the course: As you consider the range of topics that we've discussed in the course, how or about what, if at all, will you think more critically about technology in our lives and in families' lives? Thematic analysis appears in Table 1. For both classes, the two most frequent themes were thinking critically about personal technology use and recognizing the impact of technology on relationships. Two additional themes, thinking critically about how technology influences work / life balance and being aware of the digital divide and recognizing individual differences in technology use, were found to have similar frequencies between the classes.

Differences in the semesters may reflect different motivations of the individual class membership. While more targeted and controlled research is needed to test the effectiveness of critical thinking content and activities in the Families and Technology course as designed, intial evidence suggests value for a higher education course that encourages the next generation of professionals and parents' intentional ICT use.

\section{References}

American Association of Family and Consumer Sciences. (2013). Code of Ethics. Retrieved from http://www.aafcs.org/AboutUs/CodeEthics.asp

American Association of Marriage and Family Therapy. (2015). Code of Ethics. Retrieved from https://www.aamft.org/Legal_Ethics/Code_of_Ethics.aspx

Abrami, P. C., Bernard, R. M., Borokhovski, E., Wadem, A., Surkes, M. A., Tamim, R., Zhang, D. (2008). Instructional interventions affecting critical thinking skills and dispositions: A stage 1 meta-analysis. Review of Educational Research, 78(4), 1102 1134. doi:10.3102/0034654308326084

Bialik, M and Fry, R. (2019). Millennial life: How young adulthood compares with prior generations. Pew Internet. Retrieved from https://www.pewsocialtrends.org/essay/millennial-life-how-young-adulthood-todaycompares-with-prior-generations/

Bloom, B. S. (1956). Taxonomy of Educational Objectives. New York: David McKay.

Casigrahi, B. (2017). Fundamentals of teaching critical thinking in higher education. Journal of Education and Human Development, 6(3), 98-103. doi:10.15640/jehd.v6n3a11

Davies, M. (2015). A model of critical thinking in higher education. In Higher education: Handbook of theory and research (pp. 41-92). Springer.

Halpern, D. F. (2014). Thought and knowledge: An introduction to critical thinking (5th ed.). London: Psychology Press/Routledge.

International Society for Technology [ISTE]. (2016). ISTE standards for students. Retrieved from https://www.iste.org/standards/for-students 
Table 1. Thematic Analysis of Critical Perspectives from FSOS 3105

\begin{tabular}{|c|c|c|c|}
\hline Theme & $\begin{array}{l}2017 \\
\text { Frequency } \\
(\mathbf{n}=39)\end{array}$ & $\begin{array}{l}2019 \\
\text { Frequency } \\
(\mathbf{n}=37)\end{array}$ & Sample Quote \\
\hline $\begin{array}{l}\text { Thinking critically } \\
\text { about personal } \\
\text { technology use }\end{array}$ & 9 & 9 & $\begin{array}{l}\text { "I will think more critically about how } \\
\text { much time I spend on technology and what } \\
\text { I use it for." }\end{array}$ \\
\hline $\begin{array}{l}\text { Recognizing the } \\
\text { impact of technology } \\
\text { on relationships }\end{array}$ & 8 & 9 & $\begin{array}{l}\text { "Just to be more aware of the impacts on } \\
\text { our daily lives and how it affects our } \\
\text { relationships on a day to day basis...really } \\
\text { spend time with people I care about } \\
\text { without technology getting in the way." }\end{array}$ \\
\hline $\begin{array}{l}\text { Thinking critically } \\
\text { about how technology } \\
\text { influences work / life } \\
\text { balance }\end{array}$ & 5 & 6 & $\begin{array}{l}\text { "I think the balance of work and family life } \\
\text { will continuously be a stressor and need to } \\
\text { be addressed in order to maintain a healthy } \\
\text { balance. I hope to be more self-aware as } \\
\text { this begins to be a concern in my own life." }\end{array}$ \\
\hline $\begin{array}{l}\text { Being aware of the } \\
\text { digital divide and } \\
\text { recognizing individual } \\
\text { differences in } \\
\text { technology use }\end{array}$ & 6 & 5 & $\begin{array}{l}\text { "As a result of this course I plan to stay } \\
\text { more informed about the gaps and divides } \\
\text { in our communities related to technology. I } \\
\text { hope to find and create solutions that will } \\
\text { support equal access of technology for all } \\
\text { families and individuals." }\end{array}$ \\
\hline $\begin{array}{l}\text { Thinking critically } \\
\text { about the pros and } \\
\text { cons of childrens' } \\
\text { technology use }\end{array}$ & 7 & 1 & $\begin{array}{l}\text { "The many ways children today are } \\
\text { submerged in technology. I will think more } \\
\text { critically on how to limit that." }\end{array}$ \\
\hline $\begin{array}{l}\text { Changing perspective } \\
\text { to view technology as } \\
\text { a tool }\end{array}$ & 0 & 5 & $\begin{array}{l}\text { "That technology is a tool, not something } \\
\text { that can be good or bad." }\end{array}$ \\
\hline
\end{tabular}


National Council on Family Relations. (2014). Family life education content areas: Content and practice guidelines. St Paul, MN: Author. Retrieved from https://www.ncfr.org/sites/default/files/downloads/news/fle_content_and_practice_guid enes_2014.pdf

Niu, L., Behar-Horentstein, L. S., \& Garvan, C. W. (2013). Do instructional interventions influence college students' critical thinking skills? A meta-analysis. Educational research review, 9, 114-118. doi:https://doi.org/10.1016/j.edurev.2012.12.002

Olson, D. H., DeFrain, J. D., \& Skogrand, L. (2014). Marriages and families: Intimacy, diversity, and strengths (8th ed.). New York: McGraw-Hill. Chapter 3: Understanding Marriage and Family Dynamics, pp. 64-102.

Ryan, L. D. \& Deci, R. M. (2000). Intrinsic and extrinsic motivations: Classic definitions and new directions. Contemporary Educational Psychology, 25, 54-67. doi:10.1006/ceps.1999.102

Wang, F., \& Hannafin, M. J. (2005). Design-based research and technology-enhanced learning environments. Educational Technology Research and Development, 53(4), 523. doi:http://dx.doi.org/10.1007/BF02504682 